\title{
Autosomal dominant familial neurohypophyseal diabetes insipidus caused by a novel nonsense mutation in AVP-NPII gene
}

\author{
HONGBO YANG, KEMIN YAN, LINJIE WANG, FENGYING GONG, ZIMENG JIN and HUIJUAN ZHU \\ Department of Endocrinology, Peking Union Medical College Hospital, Beijing 100730, P.R. China
}

Received July 15, 2018; Accepted May 2, 2019

DOI: $10.3892 /$ etm.2019.7645

\begin{abstract}
Familial neurohypophyseal diabetes insipidus (FNDI) is a rare single-gene disorder caused by mutations of the arginine vasopressin-neurophysin II (AVP-NPII) gene. These changes impair the release of vasopressin from the posterior pituitary gland. In the present study, the AVP-NPII gene of a Chinese adult patient with central diabetes insipidus, the patient's symptomatic mother and an asymptomatic sister of the patient was sequenced. Examination of the family history revealed cases of FNDI across four generations. Gene sequencing analysis revealed a novel heterozygous mutation, c.268A $>$ T (p.Lys90Ter), in exon 2 of the AVP-NPII gene, in the patient and the patient's mother, which led to the loss of 6 cysteine residues and aberrant disulfide bonds, which is predicted to alter the mature protein structure. The present study identified a novel heterozygous nonsense mutation of the AVP-NPII gene associated with FNDI, which broadens the spectrum of known mutations associated with this disorder and contributes to the understanding of its molecular basis.
\end{abstract}

\section{Introduction}

Neurohypopheseal diabetes insipidus is a disorder caused by increased urine production and volume depletion due to vasopressin (AVP) deficiency. Most cases are linked with structural damage of the hypothalamus, pituitary stalk or posterior pituitary gland (1). Familial neurohypophyseal diabetes insipidus (FNDI) is a rare inherited disease that accounts for only $1 \%$ of central diabetes insipidus cases (2). The disorder usually presents in early childhood with polyuria and polydipsia, and follow-up evaluation frequently reveals loss of the posterior

Correspondence to: Professor Huijuan Zhu, Department of Endocrinology, Peking Union Medical College Hospital, 1 Shuai Fu Yuan, Beijing 100730, P.R. China

E-mail: shengxin2004@163.com

Abbreviations: AVP-NPII, arginine vasopressin-neurophysin II; FNDI, familial neurohypophyseal diabetes insipidus

Key words: neurohypophyseal diabetes insipidus, AVP-NPII gene, nonsense mutation pituitary bright spot on T1-weighted magnetic resonance imaging (MRI) (3-5). FNDI is caused by mutations of the arginine vasopressin-neurophysin II (AVP-NPII) gene (GenBank ID, NM_000490.4), which is located on chromosome 20 and encodes a preproprotein that is proteolytically processed to generate multiple products, including AVP, neurophysin II and copeptin (6). Biosynthesis of AVP is tightly regulated by translation and post-translational processes, including enzymatic cleavage of the AVP-neurophysin II prohormone and appropriate secretion of AVP into the circulation upon various stimuli $(7,8)$. Since the publication of the first genetic study on FNDI (9), 70 mutations have been described and all are located within the $2.5 \mathrm{~kb}$-long AVP-NPII gene. The proposed pathogenic mechanisms include aberrant preprohormone processing leading to the gradual destruction of AVP-secreting cells (10) and mutations that alter the amino acid structure of the mature AVP hormone (11).

The present study reports on a female patient with autosomal dominant FNDI linked to a novel nonsense mutation of AVP-NPII gene and her extended family. The clinical, biochemical and radiological characteristics of the patient were investigated. The novel nonsense mutation was also identified in another affected family member.

\section{Patients and methods}

Patients. A 46-year-old Chinese woman was referred to Peking Union Medical College Hospital (Beijing, China) for evaluation of acute urinary retention. A urinary catheter was placed to alleviate severe bladder distension. She reported having polyuria and polydipsia since age 13 , but had not sought any medical care, as she always had access to water. The patient was born at term without any complications and had a normal pubescence. A total of 12 additional family members spanning four generations, including the patient's mother and younger brother, also had teenage-onset of polyuria and polydipsia. Daily urine volumes varied from 6.0 to 15.0 liters. No mental retardation or delay in puberty had been identified. The average final body height was $160.1 \mathrm{~cm}$ for females and $175.2 \mathrm{~cm}$ for male members of the family. The pedigree of the family is presented in Fig. 1.

Clinical, laboratory and radiological assessments. Clinical data were collected in accordance with the Declaration of Helsinki. Written informed consent was obtained from the 
patient (IV-8), the patient's mother (III-7) and an asymptomatic sister of the patient (IV-7). A water deprivation test followed by the administration of vasopressin was performed to diagnose central diabetes insipidus as described previously (12). Enhanced MRI of the hypothalamo-hypophyseal area and pelvis was performed. The residual urine volume was measured by performing an ultrasound scan of the bladder.

Genomic DNA extraction, amplification and sequencing of the AVP-NPII gene. The AVP-NPII gene was analyzed by direct sequencing from genomic DNA extracted from leucocytes of peripheral blood with the QIAamp DNA Mini kit (Qiagen $\mathrm{GmbH})$. In brief, PCR was performed in a $40-\mu 1$ reaction volume containing $100 \mathrm{ng}$ genomic DNA, $20 \mu \mathrm{l}$ 2X GC PCR buffer, $0.1 \mu \mathrm{M}$ of each dNTP, $0.1 \mu \mathrm{M}$ of each primer and 2.5 units of rTaq polymerase (Takara Bio, Inc.) in a thermocycler (ABI 9700; Applied Biosystems; Thermo Fisher Scientific, Inc.). All genomic DNA was denatured at $94^{\circ} \mathrm{C}$ for $10 \mathrm{~min}$ and amplified with 35 cycles. For exon 1 , the cycles were programmed as $94^{\circ} \mathrm{C}$ for $30 \mathrm{sec}, 60^{\circ} \mathrm{C}$ for $30 \mathrm{sec}$ and $72^{\circ} \mathrm{C}$ for $40 \mathrm{sec}$. The cycling conditions for exons 2 and 3 were programmed as follows: Module 1 was $94^{\circ} \mathrm{C}$ for $5 \mathrm{~min}, 65^{\circ} \mathrm{C}$ for $5 \mathrm{~min}$ and $74^{\circ} \mathrm{C}$ for $5 \mathrm{~min}(1 \mathrm{cycle})$; module 2 was $94^{\circ} \mathrm{C}$ for $1 \mathrm{~min}, 65^{\circ} \mathrm{C}$ for $1 \mathrm{~min}$ and $74^{\circ} \mathrm{C}$ for $4 \mathrm{~min}$ (35 cycles); module 3 was $74^{\circ} \mathrm{C}$ for $10 \mathrm{~min}$; module 4 was a hold at $4^{\circ} \mathrm{C}$. Primers for amplification and sequencing of the AVP-NPII gene are provided in Table I. Amplified products were detected by agarose gel electrophoresis and sequenced using an ABI 3730 DNA analyzer (Applied Biosystems; Thermo Fisher Scientific, Inc.).

Three-dimensional structural models of the predicted wild-type and mutant proteins were generated and comparisons between the proteins were performed using the PHYRE2 Protein Fold Recognition Server database (http://wwwsbg.bio. ic.ac.uk/phyre2) and the SWISS-MODEL protein structure homology-modelling server (http://swissmodel.expasy.org) as reported previously (5).

\section{Results}

Clinical and MRI assessments. Diabetes insipidus was confirmed via a standard water deprivation test. After $8 \mathrm{~h}$ of water deprivation, the plasma osmolality rose from 301 to $315 \mathrm{mOsm} / \mathrm{kg}$ and the urine osmolality rose from 50 to $65 \mathrm{mOsm} / \mathrm{kg}$. $4 \mathrm{U}$ vasopressin was subsequently injected intramuscularly. Following $2 \mathrm{~h}$, the plasma osmolality decreased from 315 to $302 \mathrm{mOsm} / \mathrm{kg}$ and the urine osmolality increased from 65 to $587 \mathrm{mOsm} / \mathrm{kg}$. As presented in Fig. 2A, the cranial MRI revealed a high signal region in the posterior lobe of the pituitary gland. Serum cortisol, thyroid function, growth hormone levels, insulin-like growth factor 1 and estrogen were all within normal ranges. Pelvic MRI revealed a significantly enlarged urinary bladder (Fig. 2B). The daily urine output decreased from 151 to 21 after 1 week of treatment with $100 \mu \mathrm{g}$ 1-deamino-8-D-arginine-vasopressin three times per day. The dosage was then tapered to $50 \mu \mathrm{g}$, which was administered 3 times per day and maintained thereafter. The residual urine volume decreased from 1,250 to $4 \mathrm{ml}$ and the urinary catheter was removed.
PCR and sequencing. The AVP-NPII genes were sequenced from the patient, the patient's mother and a sister of the patient. Sequence analyses of the patient's entire AVP-NPII coding region revealed a novel heterogeneous nonsense mutation at codon 268 (c.268A $>\mathrm{T})$, which results in a substitution in exon 2 of Lys (AAG) with a stop codon (TAG) and corresponds to lysine 90 of the NPII moiety (p.Lys90Ter) (Fig. 3A). The same mutation was identified in the patient's mother (Fig. 3B), but not in the patient's sister, who had a normal phenotype (Fig. 3C). The 3-D structures of the wild-type and mutant (p.Lys90Ter) AVP-NPII proteins were modeled using the above-mentioned computational servers. As presented in Fig. 4, the Lys90Ter mutation is located in the middle of NPII and leads to the loss of 74 amino acids, including 6 cysteine residues. The loss of cysteine residues results in aberrant disulfide bonds, which is expected to alter the protein structure.

\section{Discussion}

The present study reports on a novel p.Lys90Ter mutation identified in exon 2 of the AVP-NPII gene that is linked with FNDI. The pedigree examined included cases spanning four generations, with no apparent gender preponderance among affected individuals. Similar to the observations of previously published studies on FNDI, the affected individuals in the present study were normal at birth and gradually developed symptoms of vasopressin deficiency beginning in childhood or adolescence (13). None of the subjects had any mental deficits or impaired pubescent development.

FNDI is a rare, single-gene disorder caused by mutations in the 2.5-kb AVP-NPII gene located in chromosome region 20p13 (14,15). The AVP-NPII gene has three exons: Exon 1 encodes a signal peptide, AVP, and the $\mathrm{NH}_{2}$-terminal portion of neurophysin II, exon 2 encodes the central region of neurophysin II and exon 3 encodes the $\mathrm{COOH}$-terminal region of neurophysin II and copeptin. AVP is synthesized in the supraoptic nucleus and paraventricular nucleus of the hypothalamus and then packaged into neurosecretory vesicles along with its carrier protein neurophysin II. It is then transported axonally to the neurohypophysis. Most of the mutations reported to be associated with FNDI are located in the region encoding the NPII moiety, which is the intracellular binding protein for AVP. Several mutations are localized to the coding region for signaling peptide or AVP per se. The mutant NPII is assumed to interfere with axonal transport of intracellular AVP proteolysis $(16,17)$.

A total of 7 mutations spanning all 3 exons of the AVP-NPII gene have been previously described in Chinese populations (Table II) (18-20), including 3 missense mutations in exon 2. To the best of our knowledge, the present study is the first to report on a nonsense mutation in exon 2 of the AVP-NPII gene in Chinese individuals. The mutation results in a preterm stop codon and thus a truncated NPII moiety. Wild-type pro-vasopressin has 164 amino acids and 7 disulfide bonds between all 14 cysteine residues (21). The mutant NPII loses 6 of these cysteine residues and the resultant aberrant disulfide bonds cause misfolding of the prohormone. As a result, the prohormone is likely retained within the endoplasmic reticulum and exceeds its capacity to 
Table I. Primer sequences for PCR of the arginine vasopressin-neurophysin II gene.

\section{Exon/direction}

Forward

Reverse

2

Forward

Reverse

3

Forward

Reverse
Sequences $\left(5^{\prime}-3^{\prime}\right)$
ATGATCCCCTGCACAGACAG

CTGCCCAGCCATGCCATG

TCGCTGCGTTCCCCTCCAACCCCTCGACTC CGCCCCCCCCCAGGCCCGCCCCCGCCGCGC

CCCAGGCGCCCGTGCTCACACGTCCTCCCG ССТСТСТССССТTСССТСТTCCCGCCAGAG

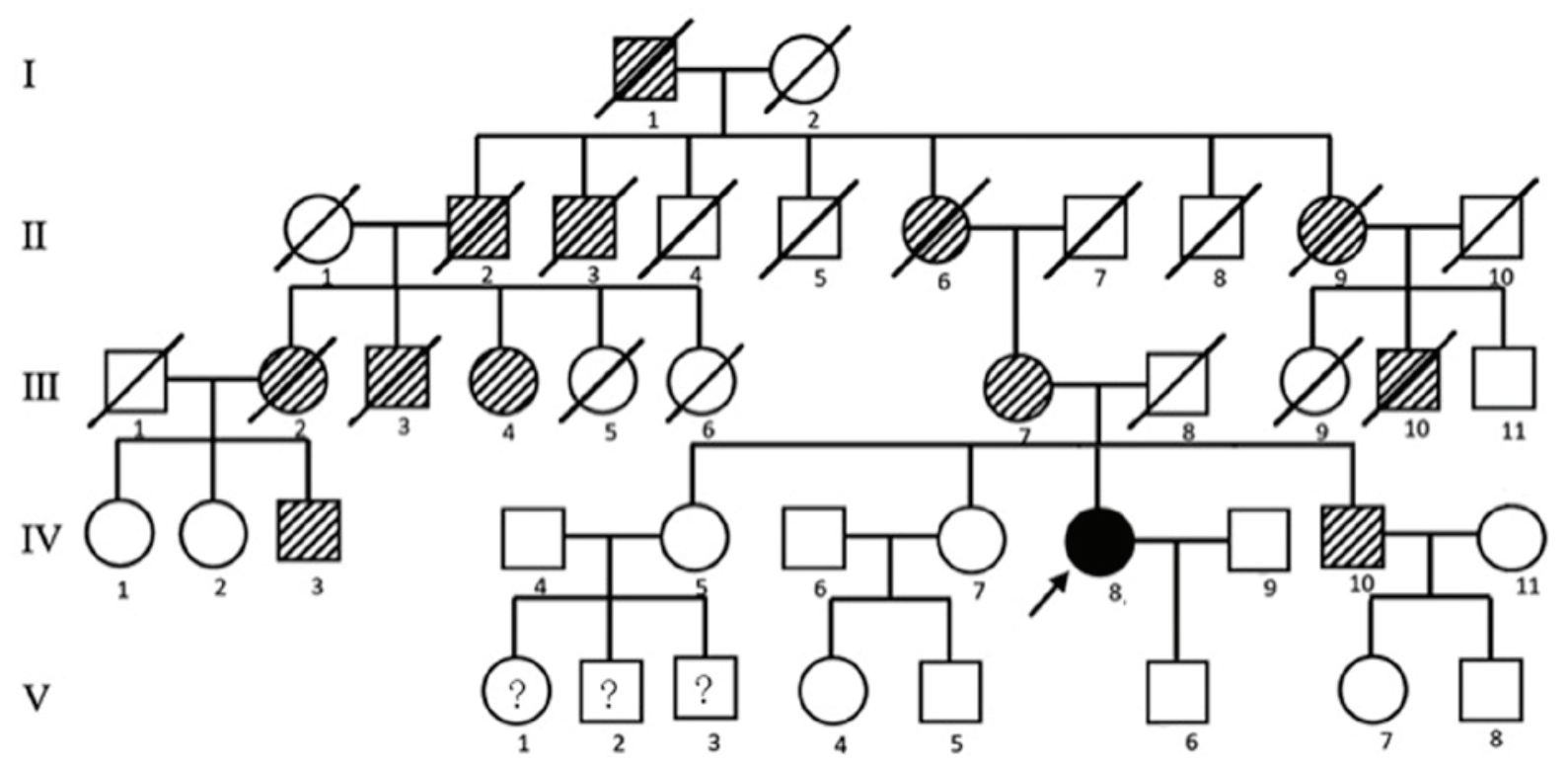

Figure 1. Pedigree of the family. The patient with diabetes insipidus is indicated by a solid symbol and an arrow. Family members with symptoms of polyuria and polydipsia are indicated by a filling of diagonal lines. Family members whose conditions were unknown are indicated with question marks. Squares indicate male and circles female subjects. Symbols that are crossed indicate deceased subjects.
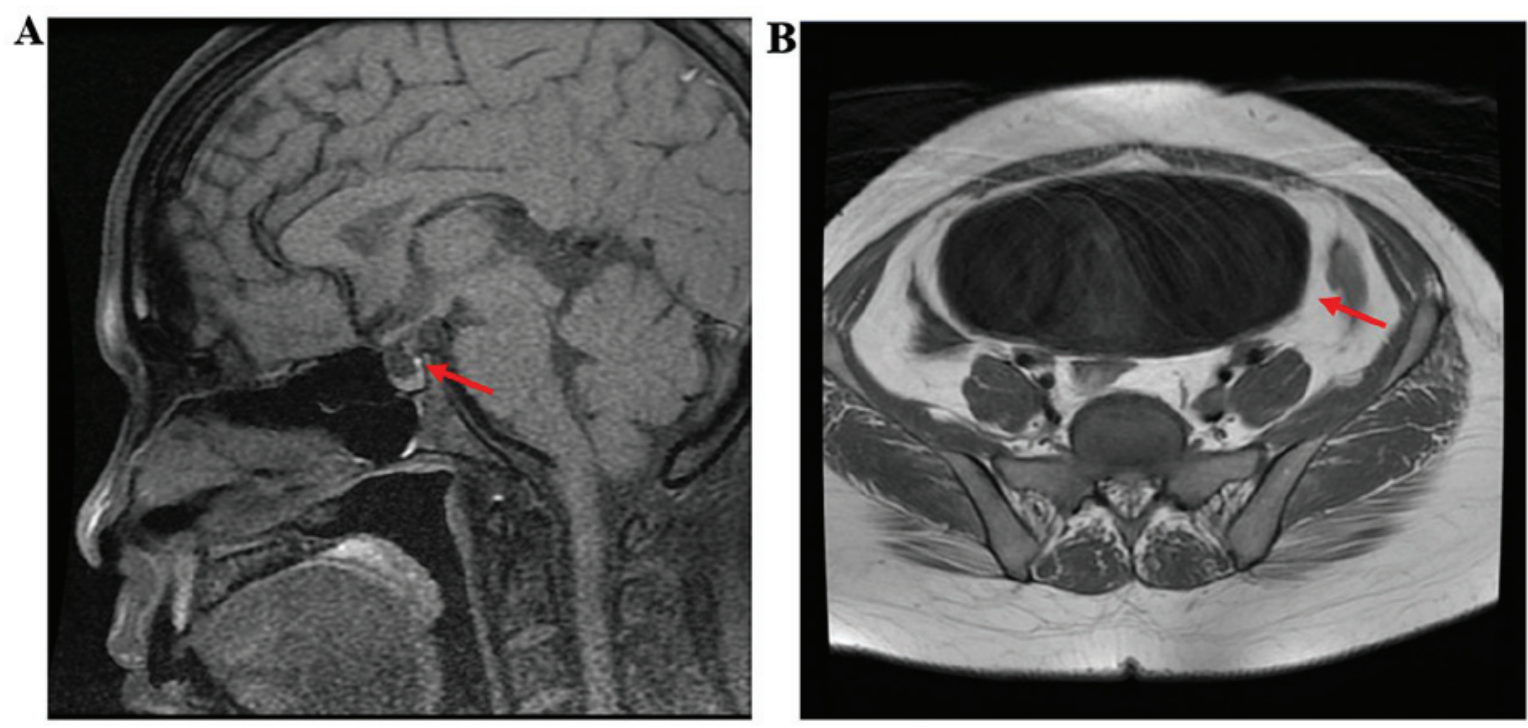

Figure 2. MRI of the pituitary gland and pelvis. (A) Sagittal MRI of the pituitary gland. A high-signal region at the posterior lobe was present. (B) MRI of the pelvis revealed a significantly enlarged urinary bladder. MRI, magnetic resonance image. 


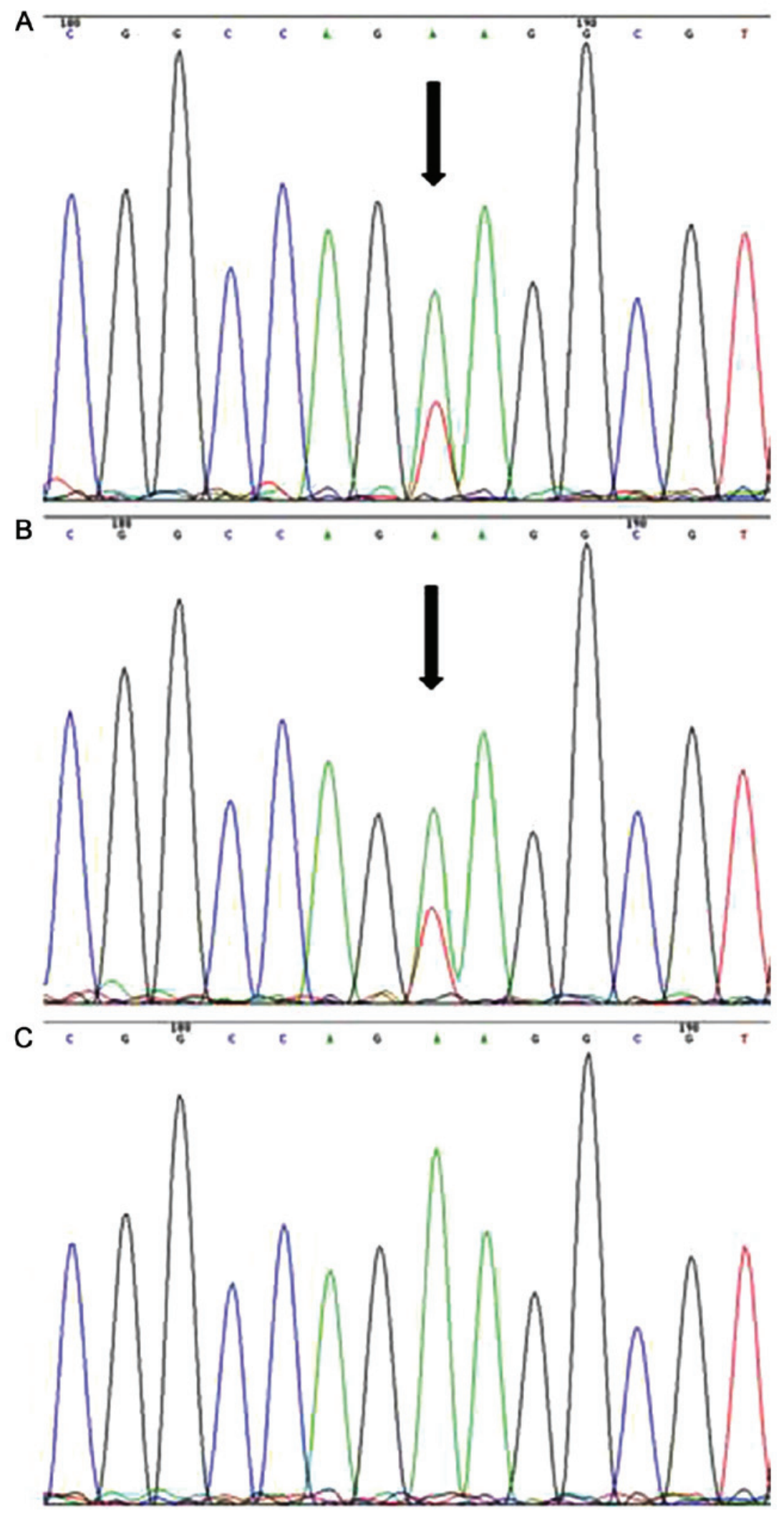

Figure 3. Automated sequencing of the AVP-NPII gene in the patient, the patient's mother and the patient's asymptomatic sister. Sequencing of the coding region within Exon 2 of the AVP-NPII gene in (A) the patient and (B) the patient's mother revealed a heterozygous missense mutation (c.268A $>$ T), as indicated by the arrow, which causes the substitution of AAG (Lys) by stop codon UAG. (C) No mutation was found in the patient's asymptomatic sister. AVP-NPII, arginine vasopressin-neurophysin II.

tolerate the 'unfolded protein response', causing stress that may trigger apoptosis $(22,23)$. However, further investigations are required to verify the molecular mechanisms underlying
FNDI. It may be hypothesized that FNDI follows a pattern of autosomal dominant inheritance, which is consistent in the present pedigree. 
Table II. Arginine vasopressin-neurophysin II gene mutations in familial neurohypophyseal diabetes insipidus reported in the Chinese population.

\begin{tabular}{lllllll}
\hline $\begin{array}{l}\text { First author } \\
\text { (year) }\end{array}$ & $\begin{array}{c}\text { Coding } \\
\text { region }\end{array}$ & $\begin{array}{c}\text { cDNA } \\
\text { mutation }\end{array}$ & $\begin{array}{c}\text { Amino acid } \\
\text { change }\end{array}$ & Mutation type & $\begin{array}{c}\text { Mode of } \\
\text { inheritance }\end{array}$ & $\begin{array}{c}\text { Family } \\
\text { history }\end{array}$ \\
(Refs.)
\end{tabular}

cDNA, complementary DNA.
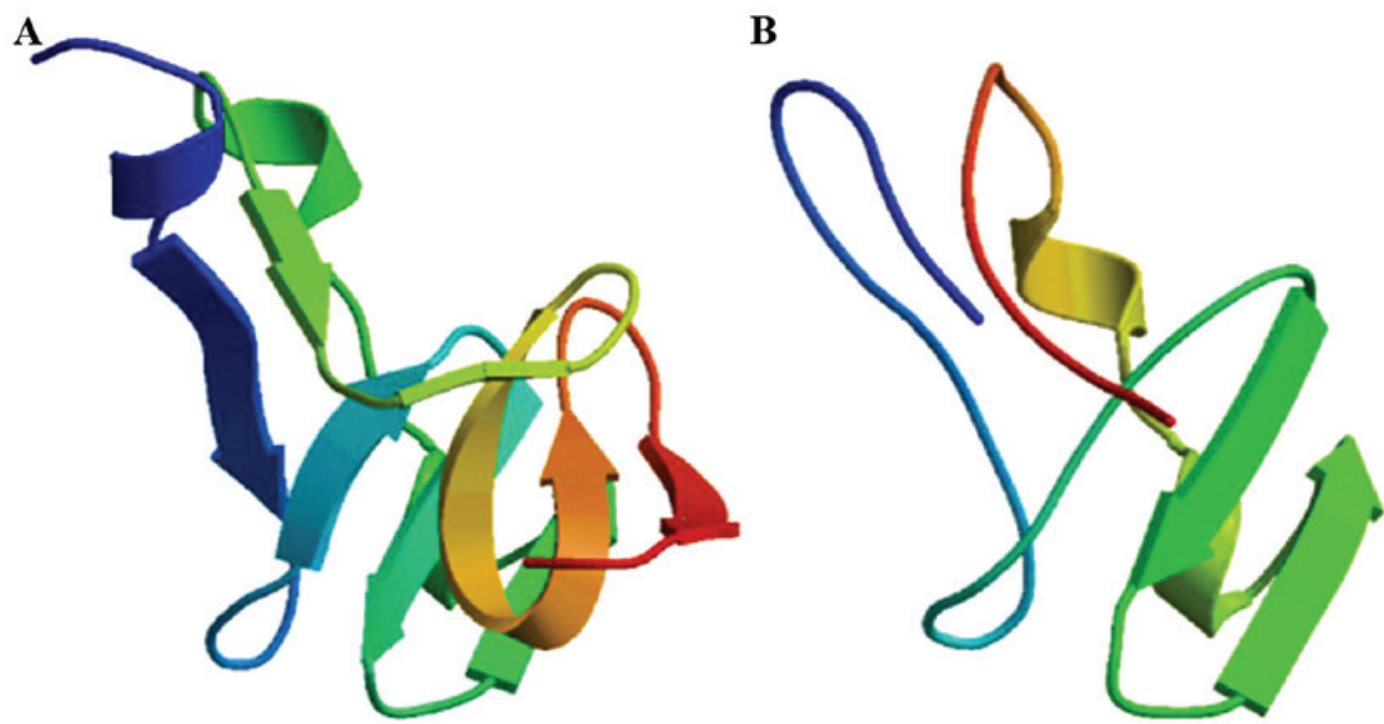

Figure 4. Three-dimensional protein structure prediction of (A) wild-type and (B) mutant (p.Lys90Ter) arginine vasopressin-NPII. The Lys90Ter mutation is located in the middle of NPII and leads to loss of 6 cysteine residues and aberrant disulfide bonds, which is likely to lead to an altered protein structure. NPII, neurophysin II.

Previous studies have described the MRI presentation of subjects with FNDI. In one study, the presence of a bright spot in the posterior lobe appeared to vary between members of the same family (5). In another case series, such a spot was entirely absent from all 13 patients (24). The MRI of the patient in the current study revealed a bright spot on the posterior lobe of pituitary gland. More serious urological complications are uncommon in these patients, as they retain a limited capacity to secrete AVP during severe dehydration.

In conclusion, the present study identified a novel nonsense mutation in the AVP-NPII gene linked with NDI in a Chinese patient whose family members shared a history of polyuria and polydipsia across four generations. This heterogeneous Lys90Ter mutation is located in the middle of NPII and leads to loss of 6 cysteine residues and aberrant disulfide bonds, which is expected to alter the mature protein structure. Although a number of studies have described variant mutations of NPII in FNDI, further elucidation of the molecular mechanisms underlying specific mutant interference with the axonal transport of intracellular AVP proteolysis are required.

\section{Acknowledgements}

Not applicable.

\section{Funding}

This work was supported by the Special Research Fund for Central Universities, Peking Union Medical College (grant no. 2017PT31004) and the CAMS Innovation Fund for Medical Science (grant no. CAMS-2016-I2M-1-002D2016I2M-1-008). 


\section{Availability of data and materials}

The datasets used and/or analyzed during the current study are available from the corresponding author on reasonable request.

\section{Authors' contributions}

HY analyzed and interpreted the patient data and wrote the primary manuscript. KY performed the PCR experiments. LW collected the blood samples of the patient and the patient's relatives and analyzed the gene sequencing data. FG supervised the experiments and data analysis. ZJ helped to interpret the patient's clinical data. HZ revised the primary manuscript and was a major contributor in writing the manuscript.

\section{Ethics approval and consent to participate}

The present study was approved by the ethics committee of Peking Union Medical College Hospital (Beijing, China).

\section{Patient consent for publication}

Written informed consent was obtained from the patient, the patient's mother and an asymptomatic sister prior to genetic testing and the publication of data and images in the present study.

\section{Competing interests}

The authors declare that they have no competing interests.

\section{References}

1. Baylis PH and Robertson GL: Vasopressin function in familial cranial diabetes insipidus. Postgrad Med J 57: 36-40, 1981.

2. Deniz F, Acar C, Saglar E, Erdem B, Karaduman T, Yonem A, Cagiltay E, Ay SA and Mergen H: Identification of a novel deletion in AVP-NPII gene in a patient with central diabetes insipidus. Ann Clin Lab Sci 45: 588-592, 2015.

3. Saglar E, Karaduman T, Ozcan M, Erdem B, Oflaz O, Sahin D, Deniz F, Ay AS and Mergen H: Identification of novel mutations in AVP-NPII gene. FEBS J 283: 131, 2016.

4. Elias PC, Elias LL, Torres N, Moreira AC, Antunes-Rodrigues J and Castro M: Progressive decline of vasopressin secretion in familial autosomal dominant neurohypophyseal diabetes insipidus presenting a novel mutation in the vasopressin-neurophysin II gene. Clin Endocrinol (Oxf) 59: 511-518, 2003.

5. Turkkahraman D, Saglar E, Karaduman T and Mergen H: AVP-NPII gene mutations and clinical characteristics of the patients with autosomal dominant familial central diabetes insipidus. Pituitary 18: 898-904, 2015.

6. Gainer H, Yamashita M, Fields RL, House SB and Rusnak M: The magnocellular neuronal phenotype: Cell-specific gene expression in the hypothalamo-neurohypophysial system. Prog Brain Res 139: 1-14, 2002.

7. Murphy D and Wells S: In vivo gene transfer studies on the regulation and function of the vasopressin and oxytocin genes. J Neuroendocrinol 15: 109-125, 2003.
8. Repaske DR, Phillips JA III, Kirby LT, Tze WJ, D'Ercole AJ and Battey J: Molecular analysis of autosomal dominant neurohypophyseal diabetes insipidus. J Clin Endocrinol Metab 70: 752-757, 1990.

9. Ito M, Mori Y, Oiso Y and Saito H: A single base substitution in the coding region for neurophysin II associated with familial central diabetes insipidus. J Clin Invest 87: 725-728, 1991.

10. Christensen JH and Rittig S: Familial neurohypophyseal diabetes insipidus-an update. Semin Nephrol 26: 209-223, 2006.

11. Willcutts MD, Felner E and White PC: Autosomal recessive familial neurohypophyseal diabetes insipidus with continued secretion of mutant weakly active vasopressin. Hum Mol Genet 8: 1303-1307, 1999.

12. Trimpou P, Olsson DS, Ehn O and Ragnarsson O: Diagnostic value of the water deprivation test in the polyuria-polydipsia syndrome. Hormones 16: 414-422, 2017.

13. Rittig S, Robertson GL, Siggaard C, Kovács L, Gregersen N, Nyborg J and Pedersen EB: Identification of 13 new mutations in the vasopressin-neurophysin II gene in 17 kindreds with familial autosomal dominant neurohypophyseal diabetes insipidus. Am J Hum Genet 58: 107-17, 1996.

14. Sausville E, Carney D and Battey J: The human vasopressin gene is linked to the oxytocin gene and is selectively expressed in a cultured lung cancer cell line. J Biol Chem 260: 10236-10241, 1985.

15. Rao VV, Löffler C, Battey J, and Hansmann I: The human gene for oxy tocin-neurophysin I (OXT) is physically mapped to chromosome 20p13 by in situ hybridization. Cytogenet Cell Genet 61: 271-273, 1992.

16. Christensen JH, Siggaard C, Corydon TJ, Robertson GL, Gregersen N, Bolund L and Rittig S: Impaired trafficking of mutated AVP prohormone in cells expressing rare disease genes causing autosomal dominant familial neurohypophyseal diabetes insipidus. Clin Endocrinol (Oxf) 60: 125-136, 2004.

17. Kobayashi H, Fujisawa I, Ikeda K, Son C, Iwakura T, Yoshimoto A, Kasahara M, Ishihara T and Ogawa Y: A novel heterozygous missense mutation in the vasopressin moiety is identified in a Japanese person with neurohypophyseal diabetes insipidus. J Endocrinol Invest 29: 252-256, 2006.

18. Tian D, Cen J, Nie M and Gu F: Identification of five novel arginine vasopressin gene mutations in patients with familial neurohypophyseal diabetes insipidus. Int $\mathrm{J}$ Mol Med 38: 1243-1249, 2016.

19. Ye D, Dong F, Lu W, Zhang Z, Lu X, Li C and Liu Y: A missense mutation in the arginine-vasopressin neurophysin-II gene causes autosomal dominant neurohypophyseal diabetes insipidus in a Chinese family. Clin Endocrinol (Oxf) 78: 920-925, 2013.

20. Luo Y, Wang B, Qiu Y, Zhang C, Jin C, Zhao Y, Zhu Q and Ma X: Clinical and molecular analysis of a Chinese family with autosomal dominant neurohypophyseal diabetes insipidus associated with a novel missense mutation in the vasopressin-neurophysin II gene. Endocrine 42: 208-213, 2012.

21. Baglioni S, Corona G, Maggi M, Serio M and Peri A: Identification of a novel mutation in the arginine vasopressin-neurophysin II gene affecting the sixth intrachain disulfide bridge of the neurophysin II moiety. Eur J Endocrinol 151: 605-611, 2004.

22. Arima H, Morishita Y, Hagiwara D, Hayashi M and Oiso Y: Endoplasmic reticulum stress in vasopressin neurons of familial diabetes insipidus model mice: Aggregate formation and mRNA poly(A) tail shortening. Exp Physiol 99: 66-71, 2014.

23. Ahner A and Brodsky JL: Checkpoints in ER-associated degradation: Excuse me, which way to the proteasome? Trends Cell Biol 14: 474-478, 2004.

24. Gudinchet F, Brunelle F, Barth MO, Taviere V, Brauner R, Rappaport R and Lallemand D: MR imaging of the posterior hypophysis in children. AJR Am J Roentgenol 153: 351-354, 1989. 